other cases it seems to be the natural growth of the specimens. Capt. Carmichael, like some botanists, seems to consider species to depend on the "distinction of the character" that can be assigned for a species, rather than on the distinctness of the structure and economy of the species itself : for it must be well known to all practical naturalists that many species, which are very difficult to distinguish by characters, are nevertheless distinct, while specimens which offer, like Enteromorpha cornucopice, a striking peculiarity in external characters, easily expressed in words, are only accidental or local varieties, which can, by mere transplantation, be converted into the presumed species.

\title{
On the Liability of Shells to Injury from the Growth of a Fungus.
} By the Rev. H. H. Higgins, M.A.

It has often been observed that shells kept for a considerable time in cabinets are apt to lose much of their original freshness and beauty of appearance. This kind of injury chiefly affects such specimens as have a bright enamelled surface, which at length becomes dull and less pleasant to the touch. Several suggestions have been made with reference to the probable cause of the change, which has often been attributed to the efflorescence of saline matter absorbed by the shell; but, so far as I have observed, the specimens most liable to injury from saline incrustation belong to genera in which the shells are without enamel, as Littorina, Turritella, \&c. ; and many collectors are in the habit of steeping their specimens in fresh water for some days, before placing them in their cabinets,-a process which is said to be an effectual preservative from injury by saline efflorescence. Mr. Dennison of Woolton attributed the loss of lustre in enamelled shells to the ravages of a minute insect, but had not been able to detect the depredator. Many of the shells in my own cabinet suffered such serious injury during last winter, that I was led to investigate the cause, which indeed became obvious enough by the use of a microscope. An ordinary lens showed the enamel of the shell to be beset with small bristly points; and when a portion of the surface was scraped off and submitted to a higher magnifying power, the forms of at least two species of Fungi became apparent,-one resembling a Mucor with a globose sporangium, the other, and much more common form, exhibiting both simple aud moniliform filaments, with an abundance of minute spores, seemingly quite free. After having been carefully washed, the surface of the shell was found to be as it were engraved in some places with stellular marks, in others with striæ forming irregular reticulations-caused, no doubt, in each instance by the spreading mycelium of the Fungus. It is scarcely necessary to add that attacks of this nature need not be apprehended where shells are kept in a perfectly dry or well-ventilated place. A slight deposition of moisture does, however, frequently occur upon their surfaces whilst shells are undergoing examination, in which ease it would be a safe precaution to allow them for a while to remain exposed to the air, before returning the drawer to the cabinet.-Proc. Lit, and Phil. Soc. of Liverpool, No. 12, 1858. 


\section{$2 \mathrm{BHL}$ Biodiversity Heritage Library}

Higgins, H H. 1858. "On the liability of shells to injury from the growth of a fungus." The Annals and magazine of natural history; zoology, botany, and geology 2, 493-493.

View This Item Online: https://www.biodiversitylibrary.org/item/61856

Permalink: https://www.biodiversitylibrary.org/partpdf/58412

\section{Holding Institution}

University of Toronto - Gerstein Science Information Centre

\section{Sponsored by}

University of Toronto

\section{Copyright \& Reuse}

Copyright Status: NOT_IN_COPYRIGHT

This document was created from content at the Biodiversity Heritage Library, the world's largest open access digital library for biodiversity literature and archives. Visit BHL at https://www.biodiversitylibrary.org. 